\title{
Distribution of varicella zoster virus and herpes simplex virus in disseminated fatal infections
}

\author{
A F Nikkels, P Delvenne, C Sadzot-Delvaux, S Debrus, J Piette, B Rentier, G Lipcsei, \\ P Quatresooz, G E Piérard
}

\begin{abstract}
Aims-To study the cutaneous and visceral distribution of herpes simplex virus (HSV) and varicella zoster virus (VZV) in fatal infections.

Methods-Standard histology, immunohistochemistry (monoclonal antibodies VL8 and VL2 and polyclonal antibody IE63 directed against VZV; monoclonal antibodies IBD4 and HH2 and polyclonal antibodies directed against HSVI and HSVII) and in situ hybridisation (antiHSV and anti-VZV probes) were applied to formalin fixed, paraffin wax sections.

Results-On histological examination, Herpesviridae infection was evident in various organs including the lungs, liver and skin. In addition, immunohistochemistry and in situ hybridisation revealed the presence of HSV and VZV antigens and nucleic acids in several cell types and tissues showing no cytopathological alterations suggestive of Herpesviridae infection. The organs with histological evidence of infection also contained VZV or HSV antigens and their genes.

Conclusions-These findings suggest that organ failure in disseminated VZV and HSV infections is primarily caused by HSV or VZV induced cell damage and lysis. They also indicate that immunohistochemistry and in situ hybridisation can provide an accurate, type-specific diagnosis on formalin fixed, paraffin wax embedded tissue even when classic histological and cytological characteristics are lacking.
\end{abstract}

(f Clin Pathol 1996;49:243-248)

Keywords: varicella zoster virus, herpes simplex virus, immunosuppression, immunohistochemistry, in situ hy-

Dermatopathology,

CHU Sart Tilman,

B-4000 Liège, Belgium

A F Nikkels

G E Piérard

Department of

Pathology

$P$ Delvenne

G Lipcsei

P Quatresooz

Department of

Fundamental Virology

C Sadzot-Delvaux

$S$ Debrus

J Piette

B Rentier

Correspondence to: Dr G E Piérard.

Accepted for publication 18 October 1995 the immunocompromised host. Recent reports show a clear upward shift in the age of VZV infection and the associated mortality rate. ${ }^{1-3}$

The clinical diagnosis of varicella, herpes zoster and herpes simplex infections may be difficult, especially when the cutaneous eruption is atypical as in immunocompromised patients. ${ }^{4-8}$ Extensive visceral dissemination can occur several days before the skin lesions appear. Typical histocytological diagnostic bridisation, lethal infection.

presence of syncytial keratinocytes, Cowdry type A intranuclear inclusions, "ground-glass" nuclei, and/or limited haemorrhagic necrotic areas. However, the typical cytopathological changes are not always present and the VZV pneumonitis, which is the most frequent complication of varicella, may have non-specific histological aspects. ${ }^{9}$ Conversely, intranuclear inclusions are not always indicative of viral infection.

The mechanisms of organ dysfunction that may lead to a fatal outcome are not entirely known. Pathogenic hypotheses are based mainly on histological observations of rare necropsy reports. The direct effect of the viruses was only suspected by the presence of Cowdry type A intranuclear inclusions.

Currently, type specific identification of Herpesviridae infections on formalin fixed, paraffin wax embedded tissue is possible using polyclonal or monoclonal antibodies directed against envelope glycoproteins or nucleocapsid constituents of $\mathrm{HSV}$ and VZV. ${ }^{10-13}$ These results can be confirmed by in situ hybridisation with specific HSV and VZV nucleic acid probes. ${ }^{1415}$

During viral latency, HSV and VZV nucleic acids and some $\alpha$ or immediate early (IE) gene transcripts, but not early (E) and late (L) proteins, are present in morphologically normal cells in the dorsal root ganglia. ${ }^{1617}$ During productive VZV infection, some viral genome sequences and viral glycoproteins $\mathrm{gE}$ and $\mathrm{gB}$ have been detected in dermal cells without cytological alterations. ${ }^{15}$ Further characterisation of viral expression in organs other than skin should highlight the distribution and the pathogenesis of disseminated infections by VZV and HSV.

This study, using histology, immunohistochemistry and in situ hybridisation, shows that the distribution of VZV and HSV in various tissues and organs, collected at necropsy, of patients with visceral dissemination of HSV and VZV infection correlates with the major clinical signs. We also show that VZV and HSV can be detected in tissues lacking histopathological alterations during disseminated infections. are potentially life-threatening, particularly in clues for HSV and VZV infections include the

\section{Case}

A 73 year old man presented with acute atypical abdominal pain. The past medical history included moderate idiopathic lymphopenia, partial prostatectomy for benign hyperplasia, type II diabetes, cholecystectomy, ancient myocardial infarction, corticosteroid dependent chronic obstructive lung disease (methyl- 
prednisolone, $4 \mathrm{mg} /$ day for over 10 years), and partial gastrectomy after perforation of cardio-oesophagal peptic ulcers. A varicella-like eruption developed on his head and soon disseminated over his entire skin surface. The patient was febrile $\left(39-40^{\circ} \mathrm{C}\right)$. Histological and immunohistological evaluations of a skin biopsy specimen led to the diagnosis of varicella. Acyclovir therapy $(7.5 \mathrm{mg} / \mathrm{kg}$ every eight hours) was initiated. Two days later, the patient experienced severe respiratory distress in association with disseminated intravascular coagulation, massive hepatolysis, and acute renal insufficiency. Anti-VZV IgM titres rose after four days, while IgG titres remained negative. The patient died from multisystem failure after six days. Necropsy was carried out four hours after death.

\section{CASE 2}

A 40 year old woman presented with pain and zosteriform eruption present for three days in the L2-4 dermatomes. The relevant past medical history included centrocytic/centroblastic lymphoma, which had been treated three years before by corticosteroids, chemotherapy (cyclophosphamide, adriamycin, vincristine, prednisolone) and splenectomy. For the previous year, treatment had been limited to methylprednisolone at a dose of $8 \mathrm{mg}$ daily. Herpes zoster was diagnosed clinically and intravenous acyclovir therapy $(10 \mathrm{mg} / \mathrm{kg}$ every eight hours) was initiated. Extradermatomal satellite lesions were absent. Liver and renal function tests were not altered. Enzyme linked immunosorbent assay (ELISA) yielded evidence of past VZV and HSV infections. Two days later the patient rapidly developed hyperthermia and respiratory distress. Chest $x$ ray showed extensive bilateral interstitial infiltration suggestive of viral pneumonitis. Despite assisted ventilation in the intensive care unit, her respiratory dysfunction worsened and she died. Necropsy was carried out 12 hours after death.

\section{CASE 3}

A 29 year old man was admitted to hospital because of hyperthermia and mental confusion developing one week after a journey to Indonesia. The diagnosis of malaria (Plasmodium falciparum) was reached. The rapid deterioration of the neurological status was suggestive of cerebral malaria. A brain scan was normal and electroencephalography showed diffuse encephalopathy. Intravenous quinidine $(10 \mathrm{mg} / \mathrm{kg} /$ day) was initiated. Two days later, the patient rapidly developed severe respiratory distress $\quad \mathrm{pO}_{2} \quad 54.8 \mathrm{mmHg}$; base excess $7 \cdot 1 \mathrm{mmol} / \mathrm{l}$ ), which was treated by assisted ventilation and high dose corticosteroids. Several days later his serum hepatic enzymes activities increased (lactate dehydrogenase $32500 \mathrm{IU} / \mathrm{l}$; aspartate aminotransferase $10950 \mathrm{IU} / \mathrm{l}$; alanine aminotransferase $7280 \mathrm{IU} / 1$ ), indicating fulminant hepatitis. ELISA revealed a past episode of VZV infection (IgG 2560, IgM negative). Tests for cytomegalovirus, Epstein-
Barr virus, $H S V$, adenoviruses, influenza, parainfluenza $1,2,3$, and hepatitis $A, B$ and $C$ were repeatedly negative. No mucocutaneous lesions were observed. A severe haemorrhagic syndrome developed with worsening hepatolysis. A liver biopsy specimen showed extensive haemorrhagic necrosis with no evidence of viral infection. A bone marrow examination showed pancytopenia. Gastrointestinal bleeding, intravascular coagulation and acute renal failure developed rapidly. The patient died during liver transplantation. A necropsy was carried out the same day.

\section{Methods}

HISTOLOGICAL ASSESSMENT

Necropsy material was fixed in formalin $(10 \%$ neutral buffered formalin) and embedded in paraffin wax for routine processing and staining with haematoxylin and eosin. The histological diagnosis of Herpesviridae infection was assessed according classic criteria, including the presence of Cowdry type A intranuclear inclusions, "ground-glass" nuclei, large eosinophilic nuclei, syncytial giant cells, and areas of limited haemorrhagic necrosis. ${ }^{1819}$ Sections $5 \mu \mathrm{m}$ thick were prepared on silanised slides for immunohistochemistry and in situ hybridisation.

\section{IMMUNOHISTOCHEMISTRY}

The monoclonal and polyclonal antibodies used are listed in table 1. The VL8 and VL2 mouse monoclonal antibodies react, respectively, with the VZV glycoproteins gE and gB. ${ }^{1213}$ The rabbit polyclonal antibody antiIE63 is directed against the VZV immediate early protein (IE63). Rabbit hyperimmune serum was obtained after inoculation of a fusion protein (molecular weight $45 \mathrm{kDa}$ ). Specificity of the polyclonal antibody was controlled by western blotting, immunofluorescence and immunohistochemistry. ${ }^{20}$ The monoclonal antibody 1BD4 (Seralab, Crawley Down, UK) recognises an $89 \mathrm{kDa}$ cytoplasmic protein of HSVI and the monoclonal antibody HH2 (Seralabs) is specific for HSVII. The rabbit polyclonal antibodies anti-HSVI and anti-HSVII (Dako, Glostrup, Denmark) react with HSVI and HSVII antigens. The anti-HSV and antiVZV antibodies do not cross-react.

Immunohistochemistry was carried out at room temperature. An avidin-biotin based detection system was used for all tissues except for the liver where the alkaline phosphataseantialkaline phosphatase (APAAP) technique was chosen because of the presence of endogenous biotin. Tissue sections ( $5 \mu \mathrm{m}$ thick) on silanised slides were deparaffinised and placed in Tris buffered saline (TBS, Tris $0.15 \mathrm{M}, \mathrm{NaCl} 0.05 \mathrm{M}, \mathrm{pH} \mathrm{7.6)}$ baths. A nonimmune blocking serum (swine or rabbit, JRH Biosciences, Lenexa, Kansas, USA) containing $3 \%$ bovine serum albumin (BSA, Behring, Marburg, Germany) was applied for $30 \mathrm{~min}$ utes. After incubation with the primary antibody, biotinylated secondary antibodies (Swine anti-rabbit diluted 1 in 300 , rabbit anti-swine 
Table 1 Antibody panel

\begin{tabular}{|c|c|c|c|c|c|}
\hline Clone/ascites & Antigen & Type & Dilution & $\begin{array}{l}\text { Incubation } \\
\text { (minutes) }\end{array}$ & Source \\
\hline \multicolumn{6}{|l|}{ VZV } \\
\hline VL8 & & Mouse MAb & 1 in 20 & 30 & CHU Sart Tilman 15 \\
\hline & gB & Mouse MAb & 1 in 10 & 30 & CHU Sart Tilman 15 \\
\hline anti-IE63 & IE63 & Rabbit PAb & 1 in 300 & 60 & CHU Sart Tilman ${ }^{20}$ \\
\hline \multicolumn{6}{|l|}{ HSV } \\
\hline IBD4 & HSVI & Mouse MAb & & 90 & Seralabs \\
\hline $\mathrm{HH} 2$ & HSVII & Mouse MAb & 1 in 20 & 90 & Seralabs \\
\hline anti-HSVI & HSVI & Rabbit PAb & Prediluted & 60 & Dako \\
\hline anti-HSVII & HSVII & Rabbit PAb & Prediluted & 60 & Dako \\
\hline
\end{tabular}

$\mathrm{MAb}=$ monoclonal antibody; $\mathrm{PAb}=$ polyclonal antibody. Source: $\mathrm{CHU}$ Sart Tilman, Department of Virology, Liège; Seralabs, Crawley Down, UK; Dako, Glostrup, UK.

diluted 1 in 400; Dako) were added and the slides incubated for 30 minutes. The slides were rinsed in TBS for 20 minutes and covered by avidin-biotin complex coupled to alkaline phosphatase (ABCAP, Dako) for 30 minutes. New Fuchsin (Dako) was used as chromogen. Slides were counterstained with Mayer's haemalum and mounted in glycergel (Dako).

IN SITU HYBRIDISATION

In situ hybridisation was performed with digoxigenin labelled probes and biotinylated probes, respectively, for the detection of VZV and HSV DNA. The 16.6 kilobase $E c o$ RI-A and 14.5 kilobase $E c o$ RI-B restriction endonuclease fragments of VZV DNA corresponding, respectively, to $\mathrm{gE}$ and $\mathrm{gpB},{ }^{21}$ subcloned into pUC $9,{ }^{22}$ were labelled in vitro by random priming $^{23}$ with digoxigenin d-UTP (Boehringer, Mannheim, Germany) to be used as probes for in situ hybridisation. The biotinylated anti-HSV probe (Enzo Diagnostics, New York, USA) is derived from a mixture of two clones of HSV-DNA sequences in the BamHI site of pBR322. The insert sizes are 16.0 and 8.0 kilobases.

Tissue sections on silanised slides were deparaffinised and digested with proteinase $K$ (100 ng/ml, Boehringer) for 15 minutes. After denaturing the probe mixtures and tissue samples together at $100^{\circ} \mathrm{C}$ for five minutes, the probes were hybridised for 12 hours in a humid chamber at $37^{\circ} \mathrm{C}$. After washing, slides were incubated with an alkaline phosphatase conjugated anti-digoxigenin antibody or Streptavidin for 30 minutes. Nitroblue tetrazolium and bromo-chloro-indolylphosphate were used as chromogen substrates and nuclear fast red was used for counterstaining. Slides were dehydrated and mounted in DePex (Gurr, Poole, Dorset, UK).

The following controls for immunohistochemistry and in situ hybridisation were used. Biopsy specimens of clinically evident herpes zoster served as positive controls for VZV antibodies and nucleic acid probes. Biopsy specimens of herpes labialis and herpes genitalis were used, respectively, as controls for HSVI and II antibodies and HSV probes. Negative controls included normal skin obtained during surgery and at necropsy. Additional negative controls omitted the primary antibody or the DNA probe.

\section{Results \\ GENERAL FINDINGS \\ Routine histology}

Table 2 summarises the results of routine histological examination. Some intranuclear inclusions, "ground-glass" nuclei, large eosinophilic nuclei, and giant cells were identified in the liver, lungs and skin of case 1 , in the skin and lungs of case 2 , and in the lungs and

Table 2 Clinical, histological and virological correlations in organ dysfunction leading to fatal outcome

\begin{tabular}{|c|c|c|c|}
\hline Major clinical signs & $\begin{array}{l}\text { Predominant } \\
\text { histological findings }\end{array}$ & $I H C$ & $I S H$ \\
\hline \multicolumn{4}{|l|}{ Case 1: VZV } \\
\hline Hepatic insufficiency & $\begin{array}{l}\text { Patchy hepatocellular necrosis, } \\
\text { inclusions }\end{array}$ & + & + \\
\hline Renal insufficiency & $\begin{array}{l}\text { Tubular hydropic } \\
\text { degeneration, thrombotic } \\
\text { microangiopathy }\end{array}$ & + & + \\
\hline Pulmonary distress & $\begin{array}{l}\text { Patchy haemorrhagic necrosis, } \\
\text { inclusions }\end{array}$ & + & + \\
\hline Abdominal pain & $\begin{array}{l}\text { Ulcerations of the digestive } \\
\text { tract }\end{array}$ & + & + \\
\hline Intravascular coagulation & Thrombotic microangiopathy & $\begin{array}{l}\text { +(dendrocytes, } \\
\text { endothelial cells) }\end{array}$ & $\begin{array}{l}\text { +(dendrocytes, } \\
\text { endothelial cells) }\end{array}$ \\
\hline Varicella & $\begin{array}{l}\text { Spongiotic, vesicular } \\
\text { dermatitis, inclusions }\end{array}$ & + & + \\
\hline \multicolumn{4}{|l|}{ Case 2: VZV } \\
\hline Herpes Zoster & $\begin{array}{l}\text { Spongiotic, vesicular } \\
\text { dermatitis, inclusions }\end{array}$ & + & + \\
\hline Pulmonary distress & $\begin{array}{l}\text { Patchy haemorrhagic necrosis, } \\
\text { inclusions }\end{array}$ & + & + \\
\hline \multicolumn{4}{|l|}{ Case 3: HSVI } \\
\hline Hepatic insufficiency & $\begin{array}{l}\text { Extensive hepatolysis, } \\
\text { inclusions }\end{array}$ & + & - \\
\hline \multirow[t]{2}{*}{ Pulmonary distress } & $\begin{array}{l}\text { Patchy haemorrhagic necrosis, } \\
\text { inclusions }\end{array}$ & + & + \\
\hline & $\begin{array}{l}\text { Cortical haemorrhagic necrosis } \\
\text { of the adrenal glands }\end{array}$ & + & + \\
\hline
\end{tabular}


Table 3 Detection of VZV and HSV antigens and nucleic acids by immunohistochemistry and in situ hybridisation in cell types lacking cytopathological features indicative of infection

\begin{tabular}{|c|c|c|c|c|c|c|c|c|}
\hline \multirow[b]{2}{*}{ Subject } & \multicolumn{8}{|l|}{ Organ } \\
\hline & Skin & Digestive tract & Lungs & Thyroid & Lymph nodes & Spleen & Liver & Pancreas \\
\hline Case 1 & $\begin{array}{l}\text { Dendrocytes, } \\
\text { endothelial cells }\end{array}$ & $\begin{array}{l}\text { Smooth muscle } \\
\text { cells, glandular } \\
\text { cells }\end{array}$ & $\begin{array}{l}\text { Pneumocytes, } \\
\text { smooth muscle } \\
\text { cells, fibroblast-like } \\
\text { cells }\end{array}$ & $\begin{array}{l}\text { Endothelial cells, } \\
\text { smooth muscle } \\
\text { cells }\end{array}$ & $\begin{array}{l}\text { Mononuclear } \\
\text { cells }\end{array}$ & $\begin{array}{l}\text { Reticulated cells, } \\
\text { endothelial cells }\end{array}$ & $\begin{array}{l}\text { Periductal } \\
\text { connective tissue } \\
\text { cells }\end{array}$ & \\
\hline Case 2 & & . & $\begin{array}{l}\text { Pneumocytes, } \\
\text { smooth muscle } \\
\text { cells, fibroblast-like } \\
\text { cells }\end{array}$ & & & & $\begin{array}{l}\text { Scattered } \\
\text { hepatocytes }\end{array}$ & $\begin{array}{l}\text { Isolated } \\
\text { glandular } \\
\text { cells }\end{array}$ \\
\hline Case 3 & & $\begin{array}{l}\text { Smooth muscle } \\
\text { cells, glandular } \\
\text { cells }\end{array}$ & $\begin{array}{l}\text { Pneumocytes, } \\
\text { endothelial cells, } \\
\text { inflammatory cells }\end{array}$ & & & $\begin{array}{l}\text { Reticulated cells, } \\
\text { endothelial cells }\end{array}$ & Hepatocytes & \\
\hline
\end{tabular}

liver of case 3 . The inclusion bodies were localised in areas of haemorrhagic necrosis and/ or in the immediate vicinity. Only the above mentioned organs met the histological criteria of viral infection. Immunohistochemistry and in situ hybridisation showed that the infection was much more widespread than suspected

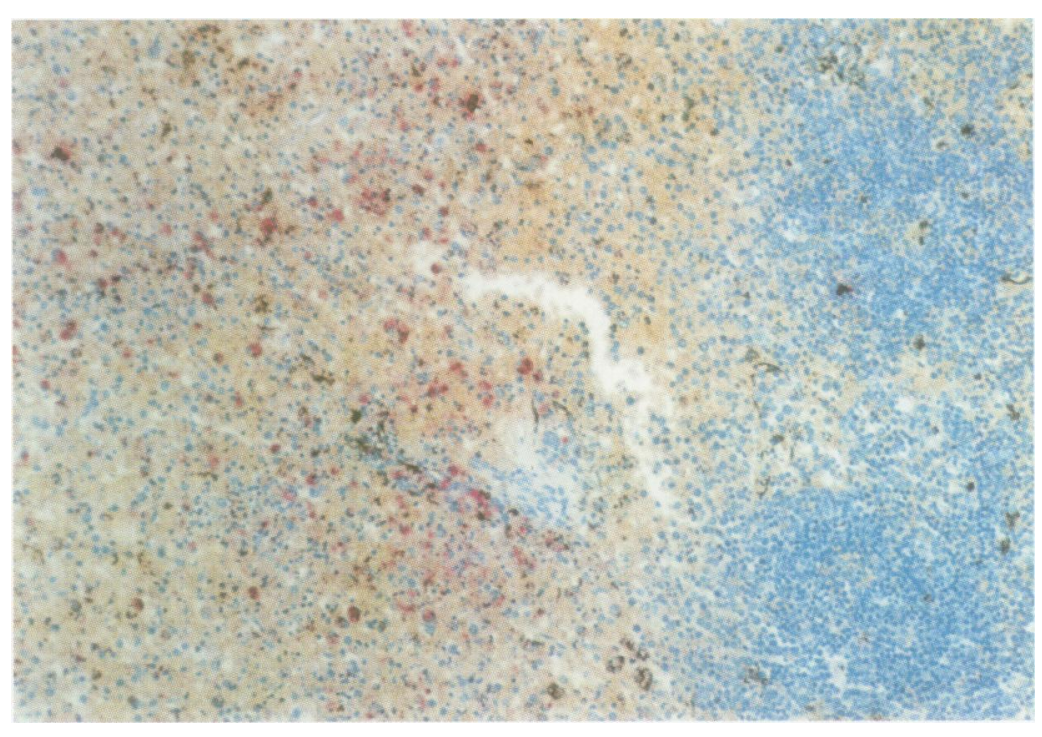

Figure $1 V Z V$ glycoprotein gE present in cells scattered in the spleen (VL8 monoclonal antibody).

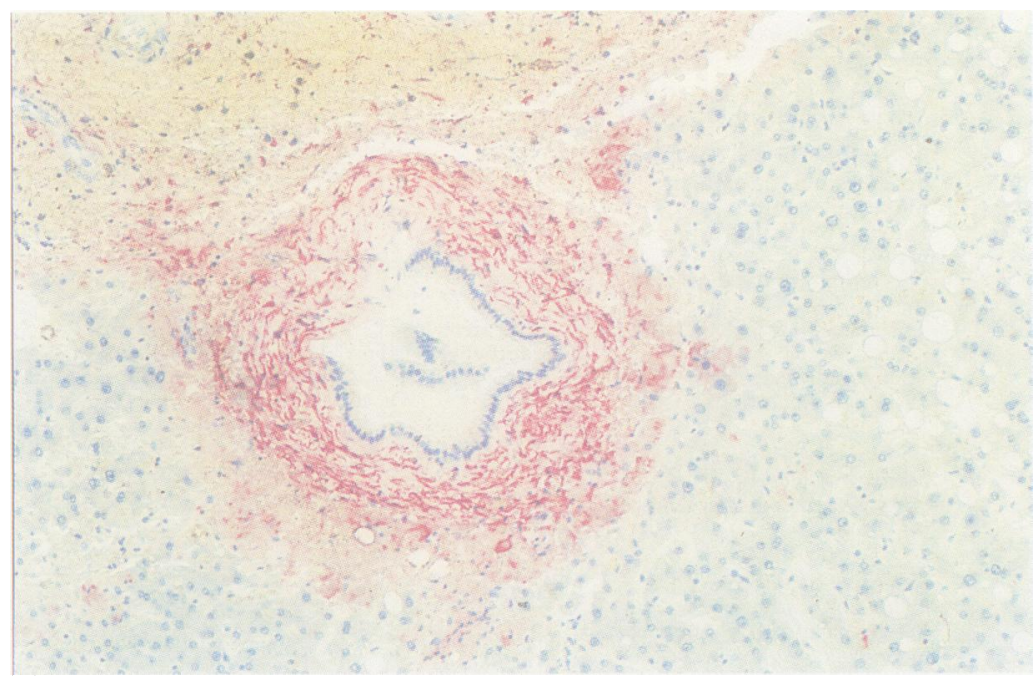

Figure 2 VZV glycoprotein gE present in a centrolobular area of the liver and in connective tissue cells surrounding a bile duct (VL8 monoclonal antibody). on histological assessment only (table 3 ). The other organs listed in tables 2 and 3 did not conform to the histological criteria for a diagnosis of viral infection.

\section{Localisation of VZV in cells}

Immunostaining with the VL8 and VL2 monoclonal antibodies essentially highlighted the cell membranes. The staining intensity was stronger for VL8 than for VL2. Weak cytoplasmic staining was observed in some infected cells. Diffuse extracellular positivity occurred in areas of extensive necrosis. The anti-IE63 polyclonal antibody predominantly stained the nuclei and, with a weaker intensity, the perinuclear zone and the cytoplasm.

The EcoRI-A and EcoRI-B fragments of VZV DNA, used as probes, produced a staining pattern that was generally restricted to the nuclei. Weak perinuclear or cytoplasmic staining was sometimes present. The information gained from immunohistochemistry and in situ hybridisation for VZV infections correlated well, although the intensity of labelling varied in the various cell populations.

\section{Localisation of HSV in cells}

The polyclonal and monoclonal antibodies directed against HSVI and II revealed membranous and cytoplasmic staining in the different infected cell lines. Cross-reactivity was observed with the polyclonal antibody directed against HSVI and II and the type-specific identification of HSV was better established using the 1BD4 and $\mathrm{HH} 2$ monoclonal antibodies. The HH2 monoclonal antibody never produced a signal in the test specimens, although the HSVII controls were positive. The polyclonal antibodies gave stronger staining signals than the 1BD4 monoclonal antibody. In situ hybridisation always revealed a predominantly nuclear signal and rarely perinuclear positivity. There was a clear correlation between the results obtained by immunohistochemistry and in situ hybridisation.

\section{CASE REPORTS}

Table 2 summarises the major clinical observations in relation to the histological findings and virological results on immunohistochemistry and in situ hybridisation (figs 1-4). 


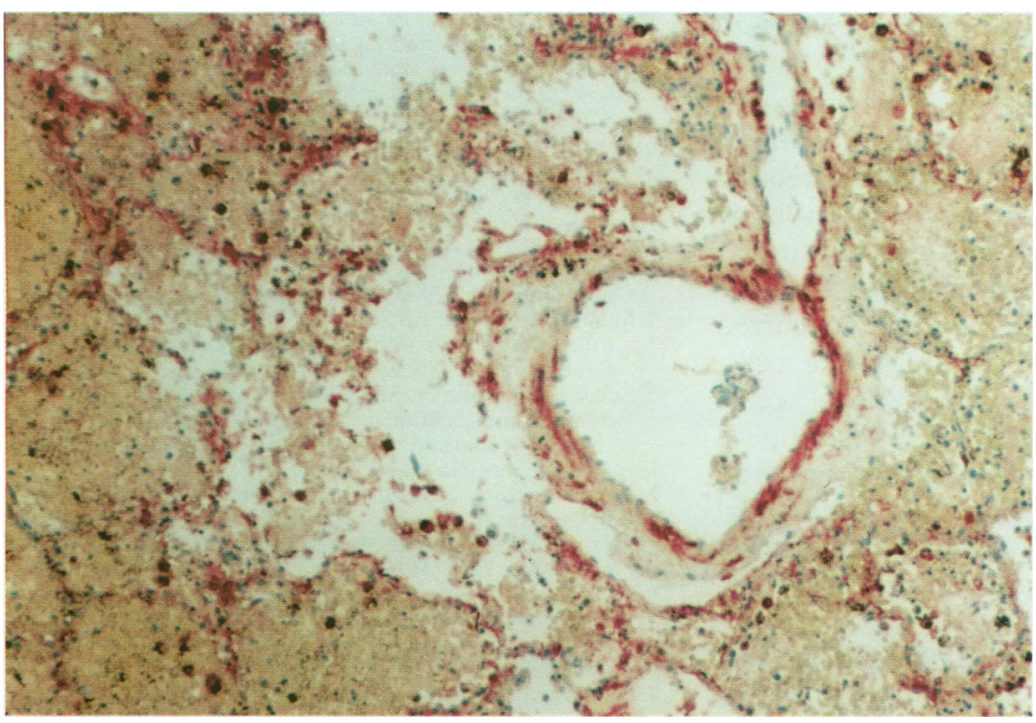

Figure 3 HSVI immunoreactivity in the lung (IBD4 monoclonal antibody).

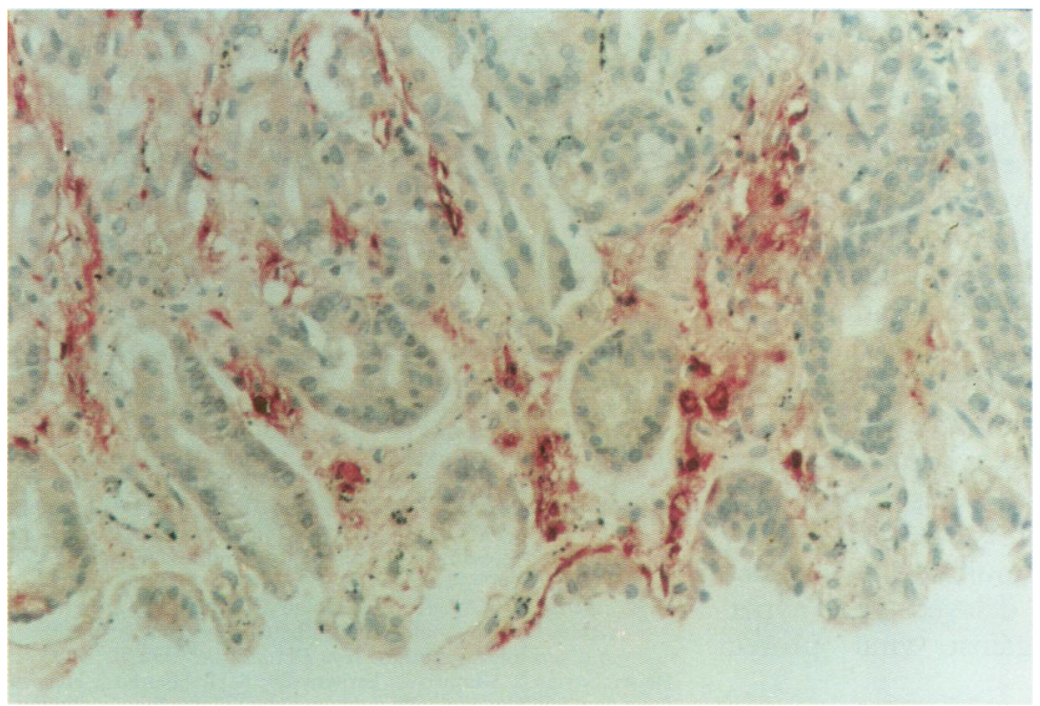

Figure 4 HSVI immunoreactivity in the lamina propria of the stomach (anti-HSVI polyclonal antibody).

\section{Discussion}

Fatal outcome following infection with VZV or HSV is rare, and few necropsy studies of such patients have been published. ${ }^{481824-26}$ In the main, the patients were severely immunocompromised, although only minor immunosuppression has been noted in other cases. ${ }^{27}$ The clinical presentation of fatal HSV and VZV infections is often atypical. The diagnosis remains difficult, particularly in the absence of typical mucocutaneous lesions. In over $80 \%$ of cases of disseminated HSV infection the diagnosis is only established at necropsy. ${ }^{5}$

Histological examination is frequently needed to confirm the diagnosis. However, the classic features of Herpesviridae infection are not always easy to recognise, and may even be absent. ${ }^{9}$ When Herpesviridae infection is suspected, type-specific identification can be achieved by nucleic acid hybridisation and antigen detection. ${ }^{10113}$ The most sensitive method to detect HSV antigens in tissue sections relies on the use of the polyclonal antibody to HSVI and HSVII. However, the monoclonal antibodies $1 \mathrm{BD} 4$ and $\mathrm{HH} 2$ are required for type-specific identification.

This study indicates that HSV or VZV antigens and nucleic acids can be present and detectable in some cell types or tissues in the absence of specific Herpesviridae cytopathological changes. This suggests that even when histological examination remains inconclusive, immunohistochemistry and in situ hybridisation can confirm the diagnosis.

In our three patients, intranuclear inclusions were found only in small amounts at the periphery of necrotic areas. In one of the cases reported by Cheatham et $a l^{18}$ intranuclear inclusions were numerous even in cells without clear cytolytic features. This patient, however, died 19 days after the cutaneous onset of varicella. It is likely that VZV infection develops very slowly in some cell types and takes time to produce the characteristic nuclear inclusions.

The results also demonstrate an in vivo cellspecific permissiveness to VZV and HSV infection. In keratinocytes, hepatocytes and pneumocytes, VZV and HSV rapidly produce a productive infection that causes host cell lysis and destruction. In other cell types, such as dermal dendritic cells, endothelial cells, smooth muscle cells, and fibroblast-like cells, viral antigens and DNA were detected before the intranuclear inclusions developed. In these cells, no cytopathological effect was observed in haematoxylin and eosin stained sections. This kind of infection does not meet the criteria of Herpesviridae latency because VZV late antigens are expressed, indicating a complete viral replicative cycle.

In some cell types, VZV and HSV are responsible for productive infection with cytopathological effects. The same viruses can, however, also induce a chronic infection with few cytopathological changes. This phenomenon is observed in patients with AIDS in whom HSV and VZV induce acute vesicular lesions or chronic wart-like cutaneous lesions. ${ }^{2829}$ Such distinct evolutions probably depend on the cytokine environment and on the activity of the and 2 anti-HSV antibodis and HSV sues. Anti-VZV antibodies and DNA prob were consistently negative in case 3 . Control normal skin and normal necropsy material were consistently negative. 
local immune system. They may also be due to a disturbed viral replicative cycle. ${ }^{30}$

The present study also shows that the extent of VZV dissemination varies from one patient to another. This variability is probably related to the cell mediated immunity and antibody status of the patients. HSV was found in similar visceral cell types as those involved in VZV infection. HSV infection, however, occurred with less prominence in fibroblast-like cells, smooth muscle cells and endothelial cells. Compared with VZV infection, HSV antigens and DNA were not detected in dermal dendritic cells, monocytes/macrophages or endothelial cells. ${ }^{13}$ Whether HSV has a tropism for various cell types similar to that of VZV remains to be established by further studies.

Another striking finding is the patchy distribution of HSV and VZV infections in organs such as the liver, lungs and spleen, mimicking the distribution observed in cutaneous infections or in cell cultures. The mechanisms limiting the extent of each infectious focus is unknown.

The detection of VZV and HSV in various cell types by immunohistochemistry and in situ hybridisation seemed to be highly correlated, and both methods were sensitive and specific. In some instances, however, immunohistochemistry is preferable to in situ hybridisation. This is particularly the case in necrotic lesions, in which immunohistochemical antigen detection revealed VZV gE, $\mathrm{gB}$ and IE63 or HSV antigens while nucleic acid hybridisation was negative. It is possible that the resistance of viral antigens to proteases during necrosis is greater than that of nucleic acids to nucleases. An identical phenomenon is observed in HSV and VZV cutaneous granulomas, which are likely to result from delayed-type hypersensitivity reactions against viral protein constituents. ${ }^{31}$

Cases 1 and 3 underline the potential severity of primary VZV or HSV infections in seronegative, adult patients. The negative HSV serology in case 3 is probably because fulminant evolution outran the development of the B cell response.

The major clinical alterations in these patients correlated well with the histological, immunohistochemical and in situ hybridisation findings. These results suggest that replication of $\mathrm{HSV}$ and VZV has a direct, causative role in multisystem organ failure, underlining the importance of early diagnosis, immune deficiency disclosure and antiviral treatment.

In conclusion, this study confirms that typespecific diagnosis of HSV and VZV infections is possible on formalin fixed, paraffin wax embedded tissue. As viral components can also be detected in cells that do not exhibit cytopathological features, immunohistochemistry and in situ hybridisation are of potential value to confirm the diagnosis of HSV and VZV infections, especially when they cannot be diagnosed on routine histological examination. The results also suggest that HSV and VZV have a direct role in the pathogenesis of multisystem organ failure.
1 Gray GC, Palinkas LA, Kelley PW. Increasing incidence of varicella hospitalisations in the United States Army and Navy personnel: are today's teenagers becoming more susceptible? Should recruits be vaccinated? Pediatrics 1990; 86:867-73.

2 Sloan DSG, Burlinson A. Shift in age in chickenpox. Lancet 1992;340:974.

3 Miller E, Vurdien J, Farrington P. Shift in age in chickenpox. Lancet 1993;341:308-9.

4 Dehertogh DA, Brettman LR. Hemorrhagic cystitis due to herpes simplex virus as a marker of disseminated herpes infection. Am $\mathcal{F}$ Med 1988;84:632-5.

5 Shlien RD, Meyers S, Lee JA, Discher R, Janowitz HD. Fulminant herpes simplex hepatitis in a patient with ulcerative colitis. Gut 1988;29:257-61.

6 Schiller GL, Nimer SD, Gajewski JL, Golde DW. Abdominal presentation of varicella-zoster infection in recipients of allogenic bone marrow transplantation. Bone Marrow Transplant 1991;7:489-91.

7 Perez-Oteyza J, Pascual C, Garcia-Larana J, Odriozola J, Rocamora A, Navarro JL. Abdominal presentation of varicella zoster infection after bone marrow transplantation. Bone Marrow Transplant 1992;9:217.

8 Stemmer SM, Kinsman K, Tellschow S, Jones RB. Fatal noncutaneous visceral infection with varicella-zoster virus in a patient with lymphoma after autologous bone marrow transplantation. Clin Infect Dis 1993;16:497-9.

9 Miliauskas JR, Webber BL. Disseminated varicella at autopsy in children with cancer. Cancer 1984;53:1518-25.

10 Martin JR, Holt RK, Langston C, Gilden DH, Richardson EP, Manz HJ, et al. Type-specific identification of herpes simplex and varicella-zoster virus antigen in autopsy tissues. Hum Pathol 1991;22:75-80.

11 Muraki R, Baba T, Iwasaki T, Sata T, Kurata T. Immunohistochemical study of skin lesions in herpes zoster. Virchows Arch A Pathol Anat Histopathol 1992;420:71-6.

12 Nikkels AF, Sadzot-Delvaux C, Cloes JM, Rentier B, Piérard GE. Granulomatous reactions following herpes zoster contain varicella zoster glycoprotein gpI. $\mathcal{F}$ Invest Dermatol 1992;98:522.

13 Nikkels AF, Debrus S, Sadzot-Delvaux C, Piette J, Delvenne $\mathrm{P}$, Rentier B, et al. Comparative immunohistochemical study of herpes simplex and varicella-zoster infections. Virchows Arch A Pathol Anat Histopathol 1993;422:121-6.

14 Nikkels AF, Delvenne P, Debrus S, Rentier B, Piérard GE. VZV glycoproteins gpI and gpII are present in dermal cells without their corresponding genome. F Cutan Pathol 1992;19:544.

15 Nikkels AF, Delvenne P, Debrus S, Sadzot-Delvaux C, Piette J, Rentier B, et al. Distribution of varicella-zoster virus gpI and gpII and corresponding genome sequences virus gpI and gpII and corresponding
in the skin. $\mathcal{F}$ Med Virol 1995;46:91-6.

16 Baringer JR. Recovery of herpes simplex virus from human sacral ganglions. New Engl $¥$ Med 1974;291:828-30

7 Mahalingam RM, Wellish M, Wolf W, Dueland AN, Cohrs $\mathrm{R}$, Vafai A, et al. Latent varicella zoster viral DNA in human trigeminal and thoracic ganglia. $N$ Engl $\mathcal{f}$ Med 1990;323:627-31

18 Cheatham WJ, Weller TH, Dolan TF, Dower JC. Varicella: report of two fatal cases with necropsy, virus isolation,
and serological studies. Am $\mathcal{f}$ Pathol 1956;32:1015-35.

19 McSorley J, Shapiro L, Brownstein MH, Hsu KC. Herpes simplex and varicella zoster: comparative histopathology of 77 cases. Int $\mathcal{F}$ Dermatol 1974;13:69-75.

20 Debrus S, Sadzot-Delvaux C, Nikkels AF, Piette J, Rentier B. Varicella-zoster virus gene 63 encodes an immediate early protein abundantly expressed during latency. $\mathcal{f}$ Virol 1995;69:3240-5.

21 Davison AJ, Scott JE. The complete DNA sequence of varicella-zoster virus. $f$ Gen Virol 1986;67:1759-816.

22 Merville-Louis MP, Sadzot-Delvaux C, Delree P, Piette J, Rentier B, Moonen G. Molecular cloning of varicellazoster virus DNA and its detection in situ in infected nerve cells. Arch Int Physiol Biochem 1987;95:B87.

23 Feinberg AP, Vogelstein B. A technique for radiolabelling DNA restriction endonuclear fragments to high specific activity. Ann Biochem 1983;132:6-13.

24 Sherman RA, Silva J, Gandour-Edwards R. Fatal varicella in an adult: case report and review of the gastrointestinal
complications of chickenpox. Rev Infect Dis 1991;13:424-7.

25 Ross JS, Fanning WL, Beautyman W, Craighead JE. Fatal massive hepatic necrosis from varicella-zoster hepatitis. massive hepatic necrosis from vastronterol 1980;84:423-7.

26 Silk HJ, Guay-Woodford L, Perez-Atayde AR, Geha RS, Broff MD. Fatal varicella in steroid-dependent asthma. $\mathcal{f}$ Allergy Clin Immunol 1988;81:47-51.

27 Close GC, Houston IB. Fatal haemorrhagic chickenpox in a child on long-term steroids. Lancet $1981 ; \mathbf{i}: 480$.

28 Disler RS, Dover JS. Chronic localized herpes zoster in the acquired immunodeficiency syndrome. Arch Dermatol 1990;126:1105-6.

29 Hoppenjans WB, Bibler MR, Orme RL, Solinger AM. Prolonged cutaneous herpes zoster in acquired immunodeficiency syndrome. Arch Dermatol 1990;126:1048mun

30 Nikkels AF, Debrus S, Sadzot-Delvaux C, Piette J, Rentier B, Piérard GE. Localization of varicella-zoster virus nucleic acids and proteins in the human skin. Neurology (in press).
leic acids and proteins in the human skin. Neurology (in press)
Nikkels

Nikkels AF, Debrus S, Delvenne P, Sadzot-Delvaux C,
Rentier B, Piérard GE. Viral glycoproteins in herpesviridae granulomas. Am $₹$ Dermatopathol 1994;16:588-94. 